\title{
Analysis of Proximate Composition and In-Vitro Antibacterial Activity of Selected Green Seweeds from South Andaman Coast of India
}

\author{
T. Sivaramakrishnan ", Lipika Biswas, Baby Shalini, K. Saravanan, \\ R. Kiruba Sankar, M.P. Goutham Bharathi and Dam Roy \\ ICAR-Central Island Agricultural Research Institute, Port Blair 744105, \\ Andaman and Nicobar Islands, India \\ *Corresponding author
}

\section{A B S T R A C T}

Ke y w o r d s
Green seaweeds,
Proximate
composition,
Methanolic extract,
Antibacterial
activity.
Article Info
Accepted:
15 October 2017
Available Online:
10 December 2017

The present study was aimed to analyse the nutritional composition and antibacterial activity of selected green macroalgae from Andaman Islands. Proximate composition was estimated for the selected four green macroalgae species namely, Halimeda macroloba, Halimeda tuna, Enteromorpha sp. and Acetabularia acetabulum. Methanol and Dimethyl Sulphoxide (DMSO) dissolved extracts of these macroalgae were tested against human and fish pathogens such as Staphylococcus aureus, Aeromonas hydrophila, Escherichia coli and Streptococcus pneumoniae. The results revealed that maximum protein content was observed in Enteromorpha sp. $(16.56 \pm 2.45)$ while minimum was observed in $A$. acetabulum $(8.123 \pm 0.89)$. All the analysed samples were high in ash content which ranged from $18.56 \pm 0.12$ to $33.67 \pm 0.23$. Among all the analysed macroalgae species, Enteromorpha sp. showed highest zone of inhibition against all the pathogens tested and $S$. aureus showed sensitivity to the methanolic extracts of all the four macroalgae species. Considerable level of protein, dietary fibre and high ash content were observed in all the analysed macroalgae species. The methanolic extract of Enteromorpha sp. was found active against all the tested pathogens. Thus macro algae can serve as a source of food protein and an ingredient of high nutritional value in human and animal diet and can even be used against pathogenic infection in human and animal treatment.

\section{Introduction}

Marine ecosystem is a complex system of diverse group of organisms living in close association with each other under constant pressure of competition, predation and hostile environment. Macroalage are also continually in contact with various dangerous microbes which they have seemingly defended, through the production of various secondary metabolites which have broad spectrum of biological activity such as anti-oxidative, antimicrobial, cytotoxic, anti-fungal and anti- helminthic (Kolanjinathan et al., 2009 and Radhika et al., 2012). Antibacterial agents found in the seaweeds include amino acids, terpenoids, phlorotannins, acrylic acid, phenolic compounds, steroids, halogenated ketones and alkanes, cyclic polysulphides and fatty acids (Mtolera and Semesi, 1996). This aids in limiting the growth and development of potentially dangerous bacteria, viruses, fungi and epibionts on the macroalgae (Perez and Avila, 1990). The bioactive compounds 
present in the macrolage serve as a compound of great interest in the pharmaceutical industry. The ability of the pathogens to develop resistance against the existing drugs and the side effects caused by those drugs has led to the extensive screening of new antimicrobial compounds for the development of novel drugs which may serve as an effective alternative to overcome the emergence of multi-drug resistant pathogens and the infectious diseases caused by these organisms (Kayalvizhi et al., 2012).

Antibacterial activity of macroalgae belonging to all the three classes has been reported by various authors. Hellio, Brrener, Pons, Cotlenceau and Borgongman (2000) have reported the antimicrobial activity of macroalgae extracts on fungi and bacteria. Kolanjinathan et al., (2009) has reported highest antibacterial activity in class Rhodophyceae (80\%) followed by Chlorophyceae (62.5\%) and Phaeophyceae (61.9\%).

Andaman and Nicobar Islands are rich in macroalgae beds covered with around 105 different marine macroalgae or seaweed species, of which $39.38 \%$ is dominated by Rhodophyceae, $35.71 \%$ by Chlorophyceae and $25 \%$ by Phaeophyceae (Mohanraju and Tanushree, 2012). Karthick, Mohanraju, Ramesh, Murthy and Narayana (2013) reported that South Andaman water serves as home for more macroalgae species compared to North Andaman, which comprises of around 29 species belonging to Chlorophyceae, 23 species of Phaeophyceae family and 20 species belonging to Rhodophyceae. According to Palanisamy (2012) Caulerpa sp., Halimeda sp., Enteromorpha sp., Ulva sp., Chaetomorpha sp., and Acetabularia sp., are the major genera proliferating along the South Andaman coast. The present investigation thus focuses on assessing the nutritional composition and antibacterial property of selected green macroalage from South Andaman Island.

Since ancient times, macroalage served as a source of food for coastal communities around the globe and in various Asian countries such as Japan, China, Korea, Indonesia, Vietnam and Taiwan (Dere et al., 2003) they are still consumed as food and food additive in fresh as well as dried form suggesting that they are prominent source of vitamins, minerals, carbohydrates, dietary fibres and considerable level of proteins. The appealing anti-cancer, anti-thrombotic, anticoagulant, anti-inflammatory and anti-viral properties recorded in the macroalage extracts is attributed to the presence of nutritive compounds such as fucoidan, xylans, ulvans (polysaccharides), appreciable levels of a $\omega 3$ and $\omega 6$ fatty acids and other micronutrients such as vitamins (vitamin $\mathrm{B}_{12}, \mathrm{C}$ and $\mathrm{E}$ ) and minerals such as iodine, calcium, iron, etc. (Angstwurm, 1995 and Charreau, 1997). These nutritional constituents helps in preventing cardiovascular disease, cancer, anaemia, chronic fatigue syndrome and it also strengthens immune system, which serves as the major reason for their demand in the pharmaceutical and therapeutic industries. Hydrocolloids such as agar, alginin and carrageenan are also extracted from seaweeds, for which there are great demands in the Indian market (Ramalingam et al., 2000).

\section{Materials and Methods}

\section{Collection and preparation of sample}

Four green macroalgae species such as $H$. tuna, H. macroloba, Enteromorpha sp. and $A$. acetabulum were collected along the South Andaman coast at three different locations during low tide and GPS coordinates for each sampling station was recorded. The samples were thoroughly washed with seawater to remove epiphytes, sand and pebbles and 
immediately transported to the laboratory in ice box, where they were washed with freshwater to remove salt. The samples were shade dried at room temperature for 3-4 days. The dried samples were then homogenised with pestle and mortar and stored at $4{ }^{\circ} \mathrm{C}$ for further analysis.

\section{Analysis of proximate composition}

Proximate composition of the samples was determined by adopting the methods of Association of Official Analytical Chemists (AOAC, 1995). Moisture content of the sample was estimated using hot air oven at $100 \pm 2{ }^{\circ} \mathrm{C}$. Total ash content was determined by dry ashing method using Muffle furnace at 550-650 ${ }^{\circ} \mathrm{C}$. Micro Kjeldahl technique was used to determine the elemental nitrogen content, from which the protein fraction was calculated using the nitrogen-protein conversion factor (6.25).

\section{Preparation of Extract}

One gram each dried macroalage samples was dissolved in $25 \mathrm{ml}$ of $80 \%$ methanol and kept for overnight incubation in orbital shaking incubator. The samples were then centrifuged at $4500 \mathrm{rpm}$ for 10 minutes, and then the supernatant was filtered with Whattman no. 1 filter paper. The filtrate was evaporated at $50^{\circ}$ $\mathrm{C}$ in a vacuum rotary evaporator. The concentrated extracts were transferred to petri plates and kept at $50^{\circ} \mathrm{C}$ in hot air oven for complete evaporation of the solvent and based on the yield; the extract was diluted in $80 \%$ methanol and DMSO separately, to acquire a concentration of $10 \mathrm{mg} / \mathrm{ml}$. The extracts were then tested for their antibacterial activity against the selected pathogens.

\section{Bacterial strains}

The extracts were tested against four pathogenic bacteria namely, Staphylococcus aureus (ATCC 25923), Aeromonas hydrophila (ATCC 35654), Escherichia coli (ATCC 4157) and Streptococcus pneumonia (ATCC 49619) received from Microbiologics, USA.

\section{Antibacterial assay}

The antibacterial susceptibility test was carried out by agar well diffusion method (Holder and Boyce, 1994). Bacterial strains were inoculated in nutrient broth and also in Luria Bertani broth and incubated at $37^{\circ} \mathrm{C}$ for 18-24 hours. Mueller Hinton agar plates were prepared and $50 \mu \mathrm{l}$ of bacterial culture was evenly spread throughout the plate using sterile glass L- rods. A total of 4 wells were made in each plate by using a sterile cork borer. Both methanol and DMSO dissolved macroalage extracts $(50 \mu \mathrm{l}$ each) were loaded separately into the wells in duplicate. Likewise, negative control (solvent alone) and positive control (streptomycin) were also prepared in duplicate. The plates were incubated at $37^{\circ} \mathrm{C}$ for 24 hours. The zone of inhibition was measured after 24 hours from the periphery of the well.

\section{Statistical analysis}

Data were expressed as mean \pm standard error in three replicates. All the statistical analysis was carried out using SPSS 16.0. To determine whether there were any difference among the means, one way analysis (ANOVA) and the Duncan's multiple range test were applied to the result and $\mathrm{P}$ values < 0.05 regarded to be significant.

\section{Results and Discussion}

\section{Proximate composition of macroalage}

Biochemical composition of all the green macroalage in terms of moisture, ash, crude fat, crude protein and crude fibre are given in 
Table 1 and Figure 1. The moisture content of the macroalage ranged from $71.94 \pm 1.14$ to $82.35 \pm 1.19$. Among the four species of macroalgae studied, A. acetabulum showed the highest moisture content $(82.35 \pm 1.19)$ followed by Enteromorpha sp. (78.78 \pm 0.41$)$, $H$. macroloba $(73.01 \pm 1.42)$ and $H$. tuna (71.94 \pm 1.14$)$. The ash content varied from $18.56 \pm 0.12$ to $33.67 \pm 0.23$. The total lipid content was low in all macroalgae samples $(0.69 \pm 0.58$ to $3.22 \pm 0.09)$ in which $A$. acetabulum showed the maximum content and minimum was observed in $H$. tuna.

The range of crude protein $(\%)$ varied from $8.123 \pm 0.89$ to $16.56 \pm 2.45$ which was highest in Enteromorpha sp. (16.56 \pm 2.45$)$ and lowest in $A$. acetabulum $(8.123 \pm 0.89)$. The crude fibre content varied from $3.54 \pm 0.62$ to $7.12 \pm 0.25$. The highest value of crude fibre was observed in $A$. acetabulum followed by H. macroloba, H. tuna and Enteromorpha sp.

\section{Antibacterial activity}

Methanolic extracts of four green macroalage namely $H$. tuna, H. macroloba, Enteromorpha sp. and $A$. acetabulum dissolved in methanol (Figure 2) and DMSO (Figure 3) was tested against four pathogenic bacteria namely $A$. hydrophila, $S$. aureus, $E$. coli and $S$. pneumoniae (Table 2).

\section{Aeromonas hydrophila}

DMSO dissolved extract of $H$. macroloba showed the maximum zone of inhibition $(4.25 \pm 0.75 \mathrm{~mm})$, followed by $H$. tuna $(4.15 \pm 0.15 \mathrm{~mm})$. Moderate activity was observed in Enteromorpha sp. $(3.5 \pm 0.5 \mathrm{~mm})$. In the methanol dissolved extracts of $H$. macroloba and Enteromorpha sp. an inhibition zone of $2 \pm 0.1 \mathrm{~mm}$ and $1.5 \pm 0.5 \mathrm{~mm}$ was recorded respectively. Methanol dissolved extract of $H$. tuna did not show any inhibition against the pathogen, while methanol and DMSO dissolved extracts of $A$. acetabulum did not show any zone of inhibition against the pathogen.

\section{Staphylococcus aureus}

Extracts of all the four tested seaweeds demonstrated anti-bacterial activity against Staphylococcus aureus. The maximum zone of inhibition was recorded in methanol dissolved extract of A. acetabulum (10.5 \pm 0.5 $\mathrm{mm}$ ) followed by DMSO dissolved extract of the same seaweed $(10.5 \pm 1.5 \mathrm{~mm})$. Methanol and DMSO dissolved extracts of Enteromorpha sp. showed an inhibition activity of $10 \pm 2 \mathrm{~mm}$ and $9.75 \pm 2.25 \mathrm{~mm}$. $H$. tuna and $H$. macroloba showed moderate activity against the tested pathogen.

\section{Escherichia coli}

DMSO dissolved extract of all the tested macroalage except Enteromorpha sp, was found ineffective against the pathogen. DMSO dissolved extract of Enteromorpha sp. showed maximum zone of inhibition $(16 \pm 1$ $\mathrm{mm}$ ) whereas, the methanol dissolved extract of the same species showed the least zone of inhibition $(2.5 \pm 0.5 \mathrm{~mm})$. Inhibition activity of $9.5 \pm 0.5 \mathrm{~mm}$ and $4.5 \pm 0.5 \mathrm{~mm}$ was observed in the methanol dissolved extract of $H$. macroloba and H. tuna. Both methanol and DMSO dissolved extract of $A$. acetabulum was found ineffective against the pathogen.

\section{Streptococcus pneumoniae}

The maximum zone of inhibition was observed in the methanol dissolved extract of A. acetabulum $(11 \pm 3 \mathrm{~mm})$ followed by DMSO $(9.5 \pm 0.5 \mathrm{~mm})$ and methanol $(7 \pm 1 \mathrm{~mm})$ dissolved extract of Enteromorpha sp respectively. Methanol and DMSO dissolved extract of $H$. tuna was ineffective whereas $H$. macroloba showed moderate activity against the test pathogen. 
Fig.1 Proximate composition of the selected green macroalgae: a. H. tuna, b. H. macroloba, c. Entermorpha sp. d. A. acetabulum
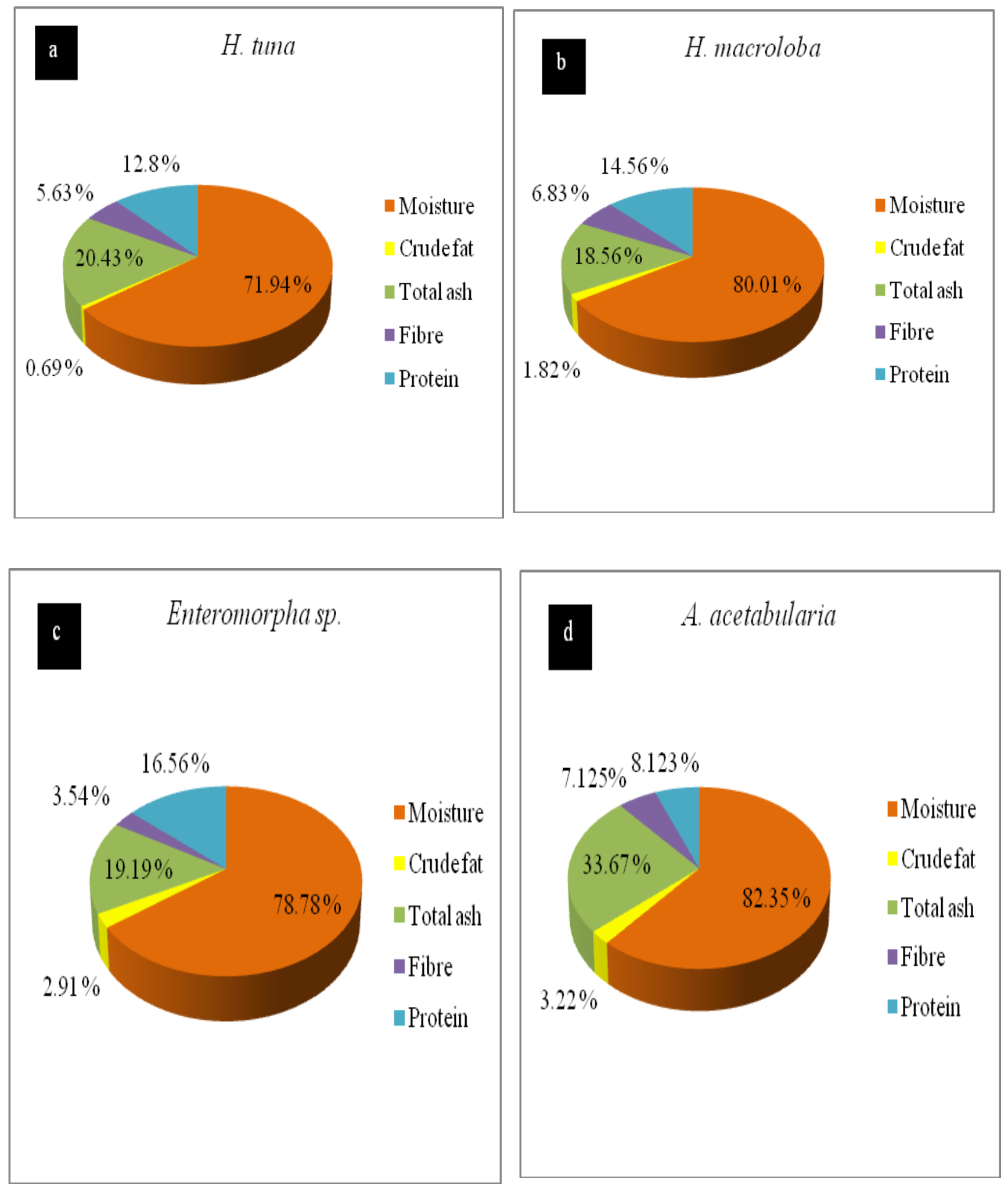
Fig.2 Antibacterial activity of methanol dissolved (methanolic) extract of green macroalage

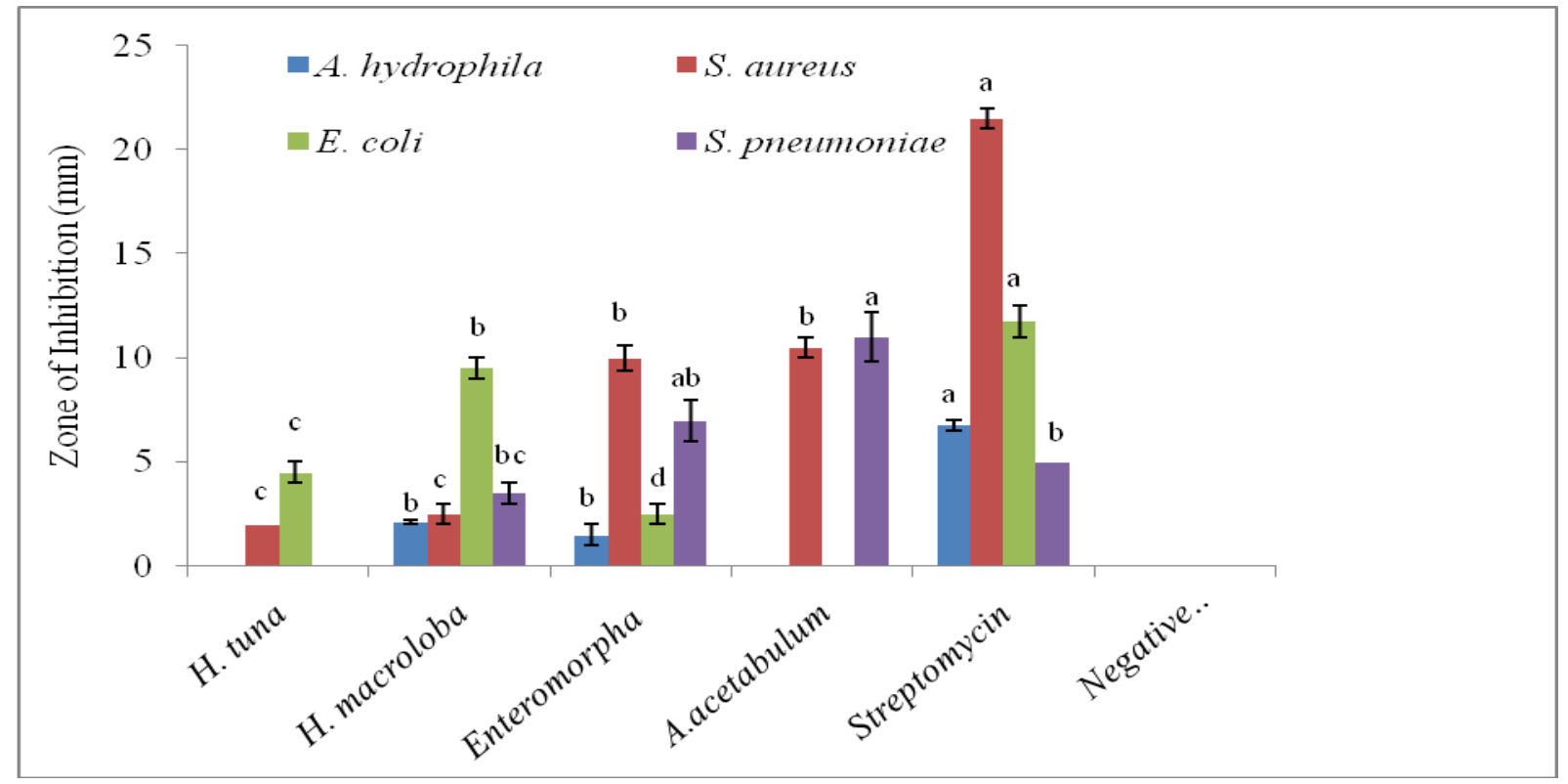

Fig.3 Antibacterial activity of DMSO dissolved extract of green macroalgae

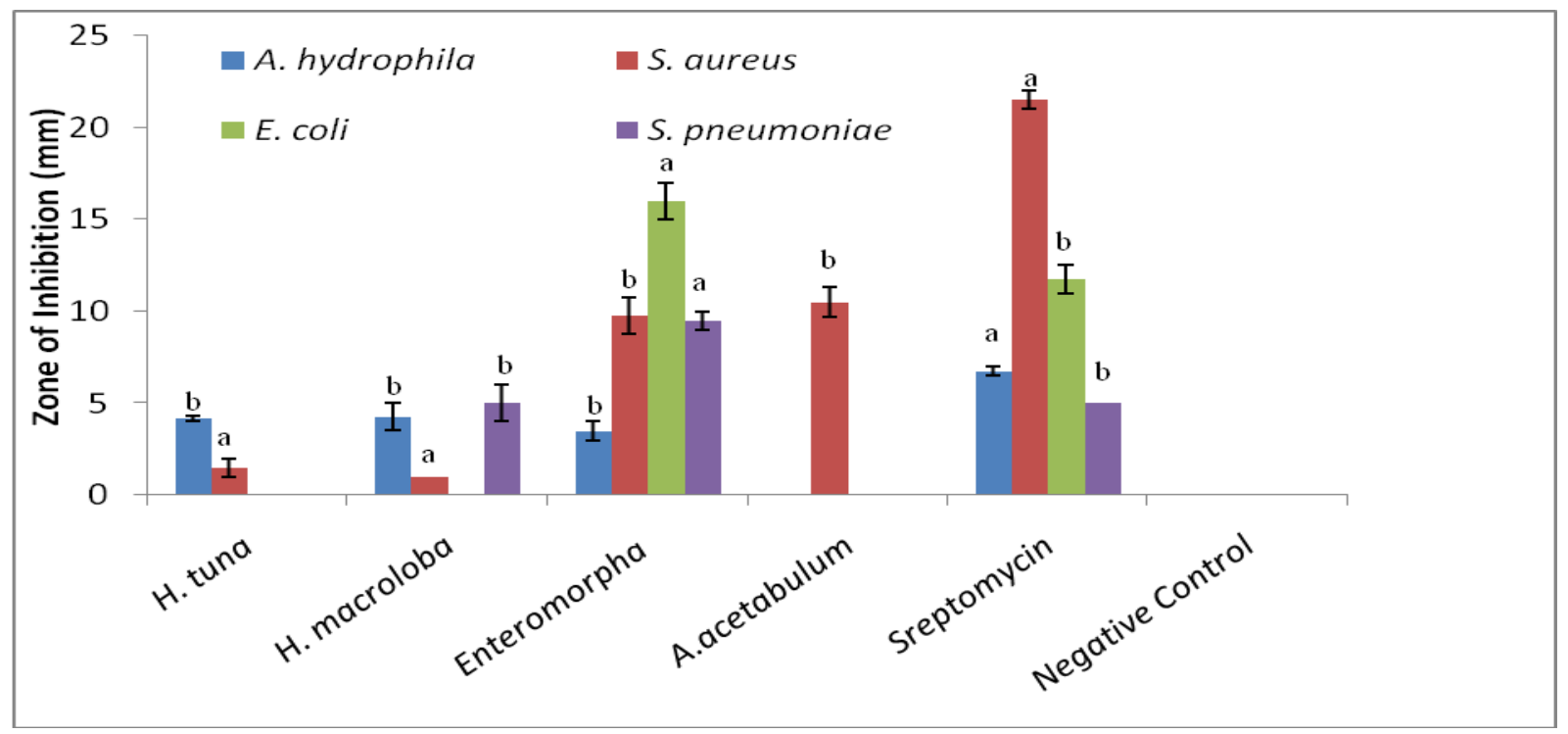

Table.1 Proximate composition of green macroalage

\begin{tabular}{lcccll}
\hline Seaweeds & $\begin{array}{c}\text { Moisture } \\
(\boldsymbol{\%})\end{array}$ & $\begin{array}{c}\text { Total Ash } \\
(\boldsymbol{\%})\end{array}$ & $\begin{array}{c}\text { Crude Fat } \\
(\boldsymbol{\%})\end{array}$ & $\begin{array}{l}\text { Crude Protein } \\
(\boldsymbol{\%})\end{array}$ & $\begin{array}{l}\text { Crude Fibre } \\
(\boldsymbol{\%})\end{array}$ \\
\hline H. tuna & $71.94 \pm 1.14^{\mathrm{b}}$ & $20.43 \pm 0.11^{\mathrm{b}}$ & $0.69 \pm 0.58^{\mathrm{c}}$ & $12.8 \pm 1.25^{\mathrm{b}}$ & $5.62 \pm 0.75^{\mathrm{a}}$ \\
H. macroloba & $73.01 \pm 1.42^{\mathrm{b}}$ & $18.56 \pm 0.12^{\mathrm{b}}$ & $1.82 \pm 0.50^{\mathrm{b}}$ & $14.56 \pm 1.76^{\mathrm{a}}$ & $6.83 \pm 0.27^{\mathrm{a}}$ \\
Enteromorpha sp. & $78.78 \pm 0.41^{\mathrm{a}}$ & $19.19 \pm 2.22^{\mathrm{b}}$ & $2.91 \pm 0.10^{\mathrm{a}}$ & $16.56 \pm 2.45^{\mathrm{a}}$ & $3.54 \pm 0.62^{\mathrm{b}}$ \\
A. acetabulum & $82.35 \pm 1.19^{\mathrm{a}}$ & $33.67 \pm 0.23^{\mathrm{a}}$ & $3.22 \pm 0.09^{\mathrm{a}}$ & $8.123 \pm 0.89^{\mathrm{c}}$ & $7.12 \pm 0.25^{\mathrm{a}}$ \\
\hline
\end{tabular}

* Each value is expressed as the mean \pm standard error $(n=3)$ 
Table.2 Antibacterial activity of methanol and DMSO dissolved macroalage extract

\begin{tabular}{cccccc}
\hline Macroalage & \multirow{5}{c}{ Bacteria } \\
Species & Solvent used & A.hydrophila & S. aureus & E. coli & S. pneumoniae \\
\cline { 2 - 6 } H. tuna & Methanol & - & $2 \pm 0^{\mathrm{c}}$ & $4.5 \pm 0.5^{\mathrm{c}}$ & - \\
& DMSO & $4.15 \pm 0.15^{\mathrm{b}}$ & $1.5 \pm 0.5^{\mathrm{a}}$ & - & - \\
H. macroloba & Methanol & $2.1 \pm 0.1^{\mathrm{b}}$ & $2.5 \pm 0.5^{\mathrm{c}}$ & $9.5 \pm 0.5^{\mathrm{b}}$ & $3.5 \pm 0.5^{\mathrm{bc}}$ \\
& DMSO & $4.25 \pm 0.75^{\mathrm{b}}$ & $1 \pm 0^{\mathrm{a}}$ & - & $5 \pm 1^{\mathrm{b}}$ \\
Enteromorphasp. & Methanol & $1.5 \pm 0.5^{\mathrm{b}}$ & $10 \pm 2^{\mathrm{b}}$ & $2.5 \pm 0.5^{\mathrm{d}}$ & $7 \pm 1^{\mathrm{ab}}$ \\
& DMSO & $3.5 \pm 0.5^{\mathrm{b}}$ & $9.75 \pm 2.25^{\mathrm{b}}$ & $16 \pm 1^{\mathrm{a}}$ & $9.5 \pm 0.5^{\mathrm{a}}$ \\
A. acetabulum & Methanol & - & $10.5 \pm 0.5^{\mathrm{b}}$ & - & $11 \pm 3^{\mathrm{a}}$ \\
& DMSO & - & $10.5 \pm 1.5^{\mathrm{b}}$ & - & - \\
Positive control & Methanol & $6.75 \pm 0.25^{\mathrm{a}}$ & $21.5 \pm 0.5^{\mathrm{a}}$ & $11.75 \pm 0.75^{\mathrm{a}}$ & $5 \pm 0^{\mathrm{b}}$ \\
& DMSO & $6.75 \pm 0.25^{\mathrm{a}}$ & $21.5 \pm 0.5^{\mathrm{a}}$ & $11.75 \pm 0.75^{\mathrm{b}}$ & $5 \pm 0^{\mathrm{b}}$ \\
Negative control & Methanol & - & - & - & - \\
& DMSO & - & - & - & - \\
\hline
\end{tabular}

* Each value is expressed as the mean \pm standard error $(\mathrm{n}=3)$; - indicates No zone of inhibition; Positive controlStreptomycin and Negative control- Methanol.

Macroalgae are known as a rich source of structurally diverse bioactive secondary metabolites which may function as antioxidative, antimicrobial, cytotoxic and antiinflammatory agents. Present study aims at exploring the nutritional composition and antibacterial activities of selected green seaweeds ( $H$. tuna, $H$. macroloba, Enteromorpha $s p$. and A. acetabulum) from South Andaman. Proximate composition of the four green macroalage collected from different locations of South Andaman was assessed. Burkholder, Burkholder and Almodovar (1971) reported that macroalgae contain $68-88 \%$ moisture which is in agreement with the results obtained in the present study. The ash content ranged from $18.56 \pm 0.12$ to $33.67 \pm 0.23$ which is nearly similar to the earlier studies in various green macroalgae (Arunkumar et al., 2014; Khairy and El-Shafay, 2013; Rohani-Ghadikolaei et al., 2012). Higher ash content is a general feature of seaweeds which indicates the presence of significant quantity of mineral compounds. In general, macroalgae contains less amount of crude lipid fibre. Burtin (2003) and Polat \& Ozogul (2008) reported that macroalgae are relatively low (1-5\% of dry weight) in lipid content. In the present study, crude lipid content observed was in the range of $0.69-3.22 \%$. Manivannan et al., (2008) analysed different group of macroalgae from Vedalai coastal waters and estimated lipid contents in Enteromorpha intestinalis (1.33\%) and Enteromorpha clathrata (4.6\%) which is in line with the results obtained in the present study. Enteromorpha sp. had a lipid content of $2.91 \%$ which was very low when compared to the results obtained by Chackroborty and Santra (2008) for Enteromorpha intestinalis (7.1\%). Parthiban et al., (2013) also recorded high crude lipid content in the green seaweed Enteromorpha intestinalis (5.30\%). The range of protein content determined in the present study $(8.123-16.56 \%)$ was similar to the findings reported by Rohani-Ghadikolaei et al., (2012); Manivannan et al., (2008); Parthiban et al., (2013); Kasimala, Mebrahtu et al., (2015) but slightly lower when compared to the reports of Murugaiyan and Narasimman (2013); Dere et al., (2003); Patarra et al., (2011). Macroalgae are widely used as a source of dietary fibre. The fibre content in the present study varied from 3.54- 
$7.12 \%$ which is very low when compared to the previous studies conducted by Patarra et al., (2011) and Ahmad, Sulaiman et al., (2012) on green macroalgae. The differences found in the present study may be due to the seasonal, spatial and temporal variations (Dawes, 1998 and Jimenez-Escrig and Cambrondon, 1999) and also due to the difference in the competence of the extraction technique followed (Tuney et al., 2007).

Antibacterial activity of the macroalgae depends upon the algal species and the solvent used for extraction. Organic solvents are commonly used for extraction of active compounds from algae. In the present study, methanol was used for extraction. According to Sangeetha et al., (2014) and Tuney et al., (2006) methanolic extracts gives higher antibacterial activity than the other extracts. Various species of marine algae have been collected and analysed for their antibacterial activity from different parts of the world. Reichelt and Borowitzka (1984) and Salvador et al., (2007) reported that members of red algae exhibited high antibacterial activity. On contrary, Khandhasamy and Arunachalam (2008) reported that members of green algae were more active when compared to other groups of algae. Karthick et al., (2015) also reported that green algae exhibited antibacterial activity against both gram positive and gram negative bacteria whereas brown and red algae showed moderate activity.

According to the study conducted by Karthikaidevi et al., (2009) methanolic extract of Halimeda tuna showed antibacterial activity against both $E$. coli and $S$. aureus and no activity was observed against Streptococcus sp. which is in agreement with the results obtained in the present study. Mtolera and Semesi (1996) investigated various green macroalage including two species of Halimeda and reported activity against S. aureus and E. coli. Tuney et al., (2007) found that the methanolic extract of Enteromorpha sp. was ineffective against $E$. coli. Glombitza (1969) established that Enteromorpha intestinalis was ineffective against $S$. aureus and Ibrahim and Lim (2015) reported the species to be ineffective against both $S$. aureus and E. coli, where as in the present study potential antibacterial activity against the respective pathogens were observed in Enteromorpha sp. Similarly, Seenivasan, Indu, Archana and Geetha (2010) reported prospective antibacterial activity in Ulva fasciata against $E$. coli. In the present study, A. acetabulum was found with the highest activity against $S$. aureus and no activity against $E$. coli, which is contradictory with the report of Karthick et al., (2015) for Acetabularia sp. against E. coli.

This study concludes that the methanolic extract of four different macroalage possess significant antibacterial activity against the tested pathogens, among which the crude extract of Enteromorpha sp. was found active against all the four pathogens. However, further study is required to isolate and characterize the bioactive compounds responsible for the activity.

Considerable levels of protein, dietary fibre and high ash content were observed in the studied macroalage. Thus macroalage can serve as source of food protein in human and animal diet and can even be used in industries as an ingredient of high nutritional value. However, further study is required to isolate and characterize the bioactive compounds responsible for the activity.

\section{References}

Ahmad, F., Sulaiman, M.R., Saimon, W., Yee, C.F., and Matanjun, P. 2012. Proximate compositions and total phenolic contents of selected edible 
seaweed from Semporna, Sabah. Malaysia Borneo Science, 31, 85-96.

Angstwurm, K. 1995. Fucoidin, a polysaccharide inhibiting leukocyte rolling, attenuatesinflammatory responses in experimental pneumococcal meningitis in rats. Neuroscience Letters, 191, 1-4.

AOAC, (1995): Official methods of analysis of AOAC International, 16th edn., AOACInt., Washington.

Arunkumar, K., Palanivelu, A., and Darsis, A. 2014. Proximate composition, nutraceutical constituents and fatty acid profile on GCMS of seaweeds collected from Balk Bay (Thondi), India. International Journal Current. Sciences, 12, 57-71.

Burkholder, P.R., Burkholder, L.M., and Almodovar, L.R. 1971. Nutritive constituents of some Caribbean marine algae. Botanica. Marina, 14, 132-135.

Burtin, P. 2003. Nutritional value of seaweeds. Journal of Environmental Agricultral Food Chemistry, 24, 498503.

Chakraborty, S., and Santra, S.C. 2008. Biochemical composition of eight benthic algae collected from Sunderban. Indian Journal of Marine Science, 37(3), 329-332.

Charreau, B. 1997. Efficiency of fucans in protecting porcine endothelial cells against complement activation and lysis by human serum. Transplantation Proceedings. 29, 889-890.

Dawes, C. J. 1998. Marine Botany. John Wiley and Sons, Inc., New York., 480 pp.

Dere, S., Dalkıran, N., Karacaoglu, D., Yildiz G., and Dere, E. 2003. The determination of total protein, total soluble carbohydrate and pigment contents of some macroalgae collected from Gemlik-karacaali (bursa) and Erdek-ormanl (balkesir) in the sea of
Marmara, Turkey. Oceanologia. 45(3), 453-471.

Glombitza., K.W. 1969. Antibacterial components in algae. Helgol. wiss. Meeres. 19, 376-384.

Hellio, G.B., Brrener, A.M. Pons, G. Cotlenceau, Y., and Borgongman, L.G. 2000. Antibacterial and antifungal activities of extracts of marine algae from Breittany. France. Use as antifouling agents. Applied microbial Biotechnology, 54,543-549.

Ibrahim, D., and Lim, S.H. 2015. In vitro antimicrobial activities of methanolic extract from marine alga Enteromorpha intestinalis. Asian Pacific Journal of Tropical Biomedicine, 5(9), 785-788.

Jimenez-Escrig, A., and Cambrondon, I.G. 1999. Evaluaciónnutricional y efectosfisiológicos de macroalgasmarinas comestibles. Archivos Latino Americos de Nutricion. 49(2), 114-120.

Kandhasamy, M., and Arunachalam, D. 2008. Evaluation of in vitro antibacterial property of seaweeds of southeast coast of India. African Journal of Biotechnology, 7, 1958-1961.

Karthick, P., Mohanraju, R., Ramesh, C.H., and Murty, K.N. 2015. Antibacterial activity of seaweeds collected from South Andaman, India. Journal of Algal Biomass Utilization, 6(1), 33-36.

Karthick., P, Mohanraju, R., Ramesh, C.H., Murthy K.N., and Narayana, S. 2013. Distribution and diversity of Seaweeds in North and South Andaman Island. Seaweed. Resource. Utilization, 35, 816.

Karthikaidevi, G., Manivannan, K., Thirumaran, G., Anantharaman, P., and Balasubaramanian, T. 2009. Antibacterial properties of selected green seaweeds from Vedalai coastal waters, Gulf of Mannar marine biospherereserve. Global Journal 
Pharmacolology, 3, 107-112.

Kasimala, M.B., Mebrahtu, L., Magoha, P.P., and Asgedom, G. 2015. A review on biochemical composition and nutritional aspects of seaweeds. Caribion. Journal Science Techology, 3, 789-797.

Kayalvizhi, K., Subramanian, V., Anantharaman, P., and Kathiresan, K. 2012. Antimicrobial activity of seaweeds from the Gulf of Mannar. International Journal of Pharmacological Application, 39(2), 306-314.

Khairy., H.M., and El-Shafay, S.M. 2013. Seasonal variations in the biochemical composition of some common seaweed species from the coast of Abu Qir Bay, Alexandria, Egypt. Pol. Academy of Sci., Institute of Oceanology, 55(2),435452.

Kolanjinathan, K., Ganeshand, P., and Govindarajan, M. 2009. Antibacterial activity of ethanol extracts of seaweeds against fish bacterial pathogens. European Review Medicine Pharmacological Science, 13(3), 173177.

Manivannan, K., Thirumaran, G., Devi, G.K., Hemalatha A., and Anantharaman, P. 2008. Biochemical Composition of Seaweeds from Mandapam Coastal Regions along Southeast Coast of India. American-Eurasian Journal Botanical, 1(2), 32-37.

Mohanraju.,R., and Tanushree, P. 2012. Seaweed distribution in South and Little Andaman. Ecology of faunal communities on the Andaman and Nicobar Islands. Springer link, 149-158 pp.

Mtolera, M.S.P., and Semesi, A.K. 1996. Antimicrobial activity of extracts from six green algae from Tanzania.Curr. Trends Mar. Bot. Res. East Afr. Reg. $211-217 \mathrm{pp}$.
Murugaiyan, K., and Narasimman, S. 2013. Biochemical and mineral contents of selected green seaweeds from Gulf of Mannar coastal region, Tamilnadu, India. International Journal of Research Plant Science, 3(4), 96-100.

Palanisamy, M. 2012. Seaweeds of South Andaman: Chidiyatapu, North Bay and Viper Island. Proc. International Day of biological Diversity, Marine Biodiversity, Uttara Pradesh State Bio Diversity Board., 49-58 Pp.

Parthiban C., Saranya, C., Girija, K., Hemalatha, A., Suresh, M., and Anantharaman, P. 2013. Biochemical composition of some selected seaweeds from Tuticorin coast. Advances in Application Science Research, 4(3), 362-366.

Patarra, R.F., Paiva, L., Neto, A.I., Lima, E., \& Baptista, J. 2011. Nutritional value of selected macroalgae. Journal Applied Phycolology, 23, 205-208.

Perez., R.M., and Avila, J.G. 1990. Antimicrobial activity of some American algae. Journal of Ethnopharmacology, 29, 111-118.

Polat, S., and Ozogul, Y. 2008. Biochemical composition of some red and brown macro-algae from the Northeastern Mediterranean Sea. International Journal of Food Science. Nutrition, 59, 566-572.

Radhika, D., Veerabahu C., and Priya, R. 2012. Antibacterial activity of some selected seaweeds from the Gulf of Mannar coast, South India. Asian Journal of Pharmacology Clinical. Research, 5, 89-90.

Ramalingam., J. R., Kaliaperumal, N., and Kalimuthu, S. 2000. Seaweed exploitation in India: Seaweed Resource Utilization, 22(1\&2), 75-80.

Reichelt, J.L., and Borowitzka, M. 1984. Antimicrobial activity from marine algae: Results of a large scale screening 
programme. Hydrobiology, 22, 158167.

Rohani-Ghadikolaei, K., Abdulalian, E., and Ng, W.K. 2012. Evaluation of the proximate, fatty acid and mineral composition of representative green, brown and red seaweeds from the Persian Gulf of Iran as potential food and feed resources. Journal of Food Science Technology, 49(6), 774-780.

Salvador, N., Gómez, G.A., Lavelliand, L., and Ribera, M.A. 2007. Antimicrobial activity of Iberian macroalgae. Scientia Marina, 71,101-113.

Sangeetha, S., Dhayanithi, N.B., and Sivakumar, N. 2014. Antibacterial activity of Sargassum longifolium and Gracilaria corticata from Gulf of Mannar against selected common shrimp pathogen. International Journal of Pharmacology Biological science, 5(2), 76-82.

Seenivasan, R., Indu, H., Archana, G., and Geetha, S. 2010. The antibacterial activity of some marine algae from south east coast of India. Journal Pharmacology Research, 3, 1907-1912.

Tuney, I., Cadirci, B.H., Unal, D., and Sukatar, A. 2006. Antimicrobial activities of the extracts of marine algae from the coast of Urla (Izmir, Turkey).Turkish journal of Biolology, 30, 171-175.

Tuney, I., Cadirci, B.H., Unal, D., Sukatar, A. 2007. In antimicrobial activities of crude extracts of marme algae from the coast of Izmir (Turkey). Fresh Environmental Bulletin, 16, 428-434.

\section{How to cite this article:}

Sivaramakrishnan, T., Lipika Biswas, Baby Shalini, K. Saravanan, R. Kiruba Sankar, M.P. Goutham Bharathi and Dam Roy. 2017. Analysis of Proximate Composition and In-Vitro Antibacterial Activity of Selected Green Seweeds from South Andaman Coast of India. Int.J.Curr.Microbiol.App.Sci. 6(12): 1739-1749. doi: https://doi.org/10.20546/ijcmas.2017.612.197 